\title{
Medieval Supposition Theory in Its Theological Context
}

\author{
STEPHEN F. BROWN
}

In his Historia calamitatum Abelard recalls a dramatic confrontation between Alberic of Rheims and himself. During the Council of Soissons (1121) Abelard's Theologia 'Summi boni', at Alberic's insistence, was being examined for doctrinal errors. Alberic, carrying a copy of the work, approached the combative Abelard and declared how startled he was by something he found in the book: since God begot God and there was only one God, how could Abelard deny that God had begotten Himself? Alberic didn't want any rational justification the suspected Abelard might want to provide for such a denial. Nor did he even want to know what the wandering teacher from Palais meant. He sought solely the words of the authority on which Abelard based himself. The undaunted Abelard told Alberic to turn over the folio of the work he was carrying. He would find there what he wanted. There indeed, to the consternation of Alberic and the disciples who accompanied him, the words from the opening chapter of Augustine's De Trinitate both justified Abelard's denial and undermined the thesis Alberic had taught for years. ${ }^{1}$ For Augustine said:

1. Peter Abelard Historia calamitatum, ed. Jacques Monfrin (Paris: Vrin. 1959), p. 84, line 751 to p. 85, line 781. Compare Theologia 'Summi boni' 2.2, ed. Heinrich Östlender, BGPTM 35/2-3 (Munster i. W.: Aschendorff, 1939), pp. 46-47. 
He who thinks God to be of such power that He begot His very self errs all the more because not only does God not exist in this way, but neither do spiritual or corporeal creatures: for there exists nothing at all which begets itself. ${ }^{2}$

Abelard's refutation of Alberic's understanding of "Deus genuit Deum" (God begot God) is further recorded in Books 3 and 4 of Theologia Christiana. ${ }^{3}$ Through the Summa sententiarum ${ }^{4}$ this AlbericAbelard debate found its way into the fourth distinction of Peter Lombard's first book of the Sentences: "Hic quaeritur utrum concedendum sit quod Deus se genuerit." 5

Gilbert de la Porrée's denial of the truth of the logically linked proposition "Deus est Trinitas"6 not only provoked discussion at the

2. Peter Abelard Historia calamitatum (Monfrin 84.765-85.769). See also Augustine De Trinitate 1.1.1 (PL 42:820; CCSL 50:28).

3. Peter Abelard Theologia Christiana 3, ed. Eligius M. Buytaert, CCCM 12 (Turnhout: Brepols, 1969), p. 235, line 1287 to p. 236, line 1334, together with 4.70136, especially no. 78, and 4.138-158 (Buytaert 297.1024-334.2184 and 335.2193344.2532).

4. Summa sententiarum 1.8 (PL 171:1087 and PL 176:60-61).

5. Peter Lombard Sententiae 1.4.1, ed. Ignatius Brady (Grottaferrata: CSB, 1971), p. 77 , line 21 .

6. Gilbert Porretanus Commentarium in Boethii De praedicatione trium personarum (PL 64:1309): "Unde et auctor recte infert dicens: Quo fit ut nec Trinitas quidem de Deo substantialiter praedicetur." Compare Nicholas M. Häring, "Notes on the Council and Consistory of Rheims (1148)," Mediaeval Studies 28 (1966): 39-59. Damien Van den Eynde contends that Lombard's critique of Gilbert de la Porrée and his followers in Sent. 1.4.2 lacks an inner connection with 1.4.1. See his "Essai chronologique sur l'oeuvre littéraire de Pierre Lombard," in Miscellanea Lombardiana (Novarra: Istituto geografico De Agostini, 1957), p. 56. While not denying that the attack on the Porretani may have been added to an earlier redaction of the Sentences, I would suggest that Praepositinus and other theologians show a closer interior link between the contents of the two chapters through their common dependence on an adequate theory regarding the supposition of terms, especially the suppositio of the term 'Deus'. For a fuller study of the connection between Peter Lombard and the school of Gilbert in the area of language, see Nicholaus M. Häring, "Petrus Lombardus und die Sprachlogik in der Trinitätslehre der Porretanerschule," in Miscellanea Lombardiana, pp. 113-127. For a broad historical perspective on Gilbert and his contemporaries, see H. C. Van Elswijk, Gilbert Porreta, sa vie, son oeuvre, sa pensée, Spicilegium Sacrum Lovaniense 33 (Leuven: Spicilegium Sacrum Lovaniense, 1966), pp. 321-364 and Lauge Olaf Nielsen, Theology and Philosophy in the Twelfth Century (Leiden: Brill, 1982). 
consistories of Paris (1147) and Rheims (1148), it also fostered logical and linguistic precisions regarding the supposition of terms by late twelfth-century theologians, such as Praepositinus. ${ }^{7}$

When Joachim of Flora attacked Peter Lombard's claim in Sentences 1.5 that "Pater non genuit divinam essentiam" and "Divina essentia non genuit Filium," not only did Joachim draw to his own teaching the condemnation of the Fourth Lateran Council (1215), he also stimulated early thirteenth-century theologians, such as William of Auxerre, to make further distinctions concerning the suppositio terminorum. 8

In brief, although modern students of medieval supposition theory have, for the most part, based themselves on medieval logic treatises, there is a rich parallel source for studying the development of the theory of the supposition of terms to be found in theological writings. For, especially in dealing with the Trinity and the Incarnation, theologians had to clarify their statements, explaining in each case whether they were speaking about the divine essence or about all or one of the divine persons, or whether they were speaking about Christ as God or Christ as man. Did they develop a certain consistency in their theory of reference or supposition? Did they find some logical principles that governed their use of language and could be applied to each proposition dealing with the Trinity? If they did, would such a theory also be applicable in statements concerning the Incarnate Son, where one is dealing with only one person, but a person with a divine and a human nature?

If we wanted to examine the success of such an endeavor, even in one medieval author, it would require a complete search of all the propositions dealing with the Trinity or the Incarnation in that author's writings. We would have to see if there were explicit or implicit rules governing the referents in each of his statements. Then we would have to see if these rules could be applied in all the other areas of his theological or philosophical discourse in a consistent way.

7. Praepositinus Summa 1, as in Paris, B. N. lat. 14,526, fol. $4^{\text {ra-va }}$.

8. Compare Enchiridion Symbolorum, ed. Denzinger-Bannwart-Schönmetzer, 32d ed. (Barcelona: Herder, 1963), nos. 431-432 [803-807], and William of Auvergne Summa aurea 1.4.4/6, ed. Jean Ribaillier (Paris and Grottaferrata: Editions du CNRS, 1980), pp. 44-49, 56-57. 
Our present task is a much more modest one. We are writing this essay as an introduction to a particular text of Walter Chatton. We will be looking at one particular theological case and showing how a small number of Chatton's predecessors dealt with that case and how they tried to develop a theory of supposition to handle it. The particular theological case is found in Lombard's Sentences 1.4 where, picking up the Alberic-Abelard debate of 1121, the Magister Sententiarum examines the truth of the proposition "Deus genuit Deum." Since the Sententiae of Lombard became the official theology textbook at Paris and Oxford before the middle of the thirteenth century, and every medieval baccalareus had as one option to present a commentary on Lombard's work as a partial requirement for becoming a Master of Theology, the commentaries baccalarii wrote on distinction 4 contain an alternate source for their theories of supposition. ${ }^{9}$

In order to understand better the text of Walter Chatton's Lectura 1.4.1.1-2, which we have edited here, we will examine the Sentences of Bonaventure (who verbally resembles William of Ockham, Chatton's chief opponent in this text), Praepositinus's Summa (he is attacked by both Thomas Aquinas and Henry of Ghent, Ockham's chief opponents), the Sentences and Summa theologiae of Aquinas, the Summa quaestionum ordinariarum of Henry of Ghent, and William of Ockham's Scriptum in I Sententiarum.

\section{BONAVENTURE}

Bonaventure, in 1.4.1.1 of his Sentences, asks the question: Should we concede the statement "Deus genuit Deum"?10 What does 'Deus' stand for in such a proposition: (1) the divine essence, (2) all three persons of the Trinity, or (3) one of the persons? Such a statement ("Deus genuit Deum") has been granted as true, according to Bonaventure, by the magistri and the sancti. But we have to get

9. For an introduction to the development of the theory of the supposition of terms in the medieval period according to logical works, see Brown, "Walter Burleigh's Treatise De suppositionibus and its Influence on William of Ockham," Franciscan Studies 32 (1972): 15-64.

10. Bonaventure Sent. 1.4.[1].1, ed. CSB, Opera Omnia 1 (Quaracchi: CSB, 1882), pp. 97-99. 
some things clear if we wish to appreciate exactly what they granted when they admitted the statement as true. Or did they mean that the divine essence begot God? Did they mean the Trinity begot God? In other words, what is the supposition of 'Deus' and 'Deum' in the proposition "Deus genuit Deum"? What do 'Deus' and 'Deum' refer to in this statement?

Bonaventure tells us as a first rule that a concrete term ('Deus' or 'albus') and an abstract term ('deitas' or 'albedo') have different references. The abstract term stands for the form or essence: 'deitas' refers to the divine essence, 'albedo' refers to the form of whiteness. The concrete term stands for the subject in whom or in which the essence or form exists: 'album' refers to a white man or a white swan, a subject in whom or in which whiteness is present, 'deitas' to a divine person in whom the divine essence is present. The need for such a distinction is clear: we could say rightly "albus currit," but not "albedo currit."

Secondly, if we further examine the concrete term ('Deus', 'albus') and find that such a term has many referents ('Deus': 'Pater', 'Filius', 'Spiritus Sanctus'; 'albus': 'homo', 'cygnus'), then if no specific reference is indicated, we should give the benefit of the doubt to whichever one would make the statement true. For example, when someone says "homo currit," the statement is true if any man at all is running. So, we should not focus on the men who are not running. As long as someone is running, the statement "homo currit" is true.

From these two rules Bonaventure arrives at this conclusion concerning the proposition "Deus genuit Deum." According to the first rule: 'Deus' is concrete, and so although the divine essence is present in each person of the Trinity, still the term 'Deus' (as well as 'Deum') refers not to the divine essence, but to a person. Then, according to the second rule: If one person, say the Father, begot another person, say the Son, then if 'Deus' stands for the Father and 'Deum' for the Son, the proposition is true. Unless 'Deus' is limited in its referents to stand only for the Son or the Holy Spirit, or 'Deum' is limited to supposit only for the Father or the Holy Spirit, then the statement "Deus genuit Deum" does not have concrete terms that are limited to specific referents for whom it would be false to say "Deus genuit Deum." As long as there is a referent ('Pater') for whom 'Deus' truly stands, and as long as there is a referent ('Filium') for whom 'Deum' truly stands, then the proposition "Deus genuit Deum" is true. This is 
the ground of meaning on which Bonaventure agrees with the magistri and sancti who accept the statement as true.

Notice that Bonaventure, in this quaestio, ${ }^{11}$ does not elaborate a theory. He simply borrows a few rules ${ }^{12}$ which help him solve a concrete problem. He says that the concrete term 'Deus' stands for a person, but he does not say why it stands for a person. Does the term 'Deus' by itself always stand for a person? Or does it stand for a person in this particular proposition because of the verb 'genuit'? As long as he does not further specify the grounds supporting his rules, he will appear, as we shall see later, to be saying the same thing as William of Ockham. In fact, however, Bonaventure does not provide us with the precise ground for his decision that "Deus" stands for a person. When Ockham does, it brings out their differences.

\section{THOMAS AQUINAS}

Thomas's discussion of the same proposition "Deus genuit Deum" provides a more theoretical discussion of supposition. 13 He focuses on the opinion of Praepositinus, ${ }^{14}$ who follows Gilbert of la Porrée. ${ }^{15}$ For Praepositinus 'Deus' by its natural supposition, ${ }^{16}$ i.e., taken simply as a term without considering the role it plays in

11. Bonaventure, in 1.4.[1].4, does ask explicitly 'utrum hoc nomen 'Deus' pro persona supponat, vel pro natura?" In response, Bonaventure does not develop a theory of supposition, but rather notes that 'Deus' is a unique term, "quia habet naturam termini communis et termini discreti: termini communis propter pluralitatem suppositorum, termini discreti ratione formae immultiplicabilis-quod proprie supponit tam naturam quam personam" (CSB 1:102-103).

12. Bonaventure Sent. 1.4.[1].1 (CSB 1:98).

13. Thomas Aquinas Summa theol. 1.38.4.

14. Thomas Aquinas Summa theol. 1.38.4.

15. Thomas Aquinas Summa theol. 1.38.4.

16. 'Natural supposition' in the era of Praepositinus is the supposition a term has just on its own. In the latter part of the thirteenth century, supposition will become defined as the property of a term in a proposition, and then natural supposition will be set aside. It does reappear, however, with a different meaning in some later authors. See Logica 'Ad rudium', ed. Lambertus M. de Rijk (Nijmegen: Ingenium, 1981), p. 51, no. 110 . 
a proposition, stands for the divine essence. In a certain statement it might be limited by the predicate or the context to stand for a particular person. In the statement "Deus genuit Deum," for example, 'Deus' has its natural supposition restricted to stand for the persona Patris. For Praepositinus, then, 'Deus' naturally stands for the divine essence, but can in a particular proposition, like "Deus genuit Deum," stand not for the divine essence but for the Father.

Aquinas is critical of this position of Praepositinus. ${ }^{17}$ It is true, Aquinas argues, that "Deus" and "deitas" both signify the divine essence. Still when we speak of what some term stands for, what its supposit is, we must consider not only its significate ('Deus' and 'deitas' both signify the divine essence), but also consider the modus significandi, the manner in which each word signifies what it signifies. Now 'Deus' and 'deitas' both signify the divine essence, but they do so in different ways. 'Deus' signifies that essence "ut in habente ipsam" (as found in a subject or supposit), whereas 'deitas' signifies that essence as an absolute form. 'Deus' by its concrete mode of signifying signifies the divine essence in a different way than 'deitas', and therefore properly supposits or stands for the divine essence not in its absolute form but as it is present in a supposit.

Aquinas adds to this, in second place, 'Deus' can sometimes properly stand for a supposit, as in the proposition "Deus genuit Deum." In other words, the concrete term 'Deus' can properly at times supposit for the essentia, ut in habente ipsam and it can also at times properly stand for the habens essentiam or supposit itself. ${ }^{18}$

Finally, if 'Deus' can stand for the essentia in habente ipsam in some cases and for the habens essentiam or supposit in other instances, then when and why does it properly stand for the former or the latter? Aquinas explains that 'Deus' properly stands for the essentia in habente ipsam when it is used in a proposition in which the predicate is affirmed of the subject 'Deus' by reason of the form of divinity that is signified by 'Deus' or 'deitas'. This is, for instance, the case in the proposition "Deus creat." The triune God creates not because He is God the Father, or God the Son, or God the Holy Spirit, but because

17. Compare Thomas Aquinas Summa theol. 1.39.4.

18. Thomas Aquinas Summa theol. 1.39.4. 
of His divine form, nature, or essence. This, however, is not the case in the proposition "Deus generat." In this instance, God generates not because of His divinity but because of His paternity. In formal terms, Aquinas declares:

"Per se [Deus] supponit pro natura communi [in habente ipsam], sed ex adiuncto determinatur eius suppositio ad personam."19

\section{HENRY OF GHENT}

Henry of Ghent deals with "Deus generat Deum" in his Summa 54.3.20 For him, 'Deus' signifies the deity, which is also what 'deitas' signifies, just as 'album' signifies whiteness, as 'albedo' does. So 'Deus', as far as what it signifies is concerned, signifies the same thing as 'deitas'. Their mode of signification, however, is different, since 'Deus' signifies per modum suppositi-or, in John Damascene's terminology, ${ }^{21}$ 'Deus' signifies the natura ut in habente ipsam-whereas 'deitas' signifies the natura per modum formae absolutae. ${ }^{22}$

Henry continues. Although 'Deus' signifies per modum suppositi, it does not signify any supposit-not one, not many-because even though 'Deus' is concrete, still it signifies something absolute in an absolute way and after the manner of something absolute, whereas all the divine supposits are relativa. For sure, 'Deus' has a different modus significandi from 'deitas', but 'Deus' also has a different modus significandi from 'persona' or 'Pater'. 'Deus' signifies the divine essence in habente ipsam per modum absoluti. 'Deus' does not signify per modum relativi, and therefore it primarily and principally stands for the essence (in habente ipsam) rather than for a person. Only when a qualifying adjunct is added can 'Deus' stand for a person, and such an adjunct (genuit) is added in the statement "Deus genuit Deum." In this case, therefore, 'Deus' supposits for the persona Patris, and thus understood, the proposition can be admitted. ${ }^{23}$

19. Thomas Aquinas Summa theol. 1.39.4.

20. Henry of Ghent Summa quaestionum ordinariarum 54.3 (Paris, 1520), 2:82r

21. Compare Henry of Ghent Summa 54.3 (2:81v).

22. Henry of Ghent Summa $54.3\left(2: 81^{v}\right)$.

23. Henry of Ghent Summa $54.3\left(2: 81^{\mathrm{v}}\right)$. 


\section{WILLIAM OF OCKHAM}

In his Commentary on the Sentences, 24 William of Ockham faces off with Thomas Aquinas and Henry of Ghent. He argues that every concrete term has to stand for that in which its form is found, as is clear from 'albus' in the proposition "Homo est albus." Here 'albus' does not stand for the form of whiteness, but for the subject of that form. In the same way, when someone says "Homo est filius Dei," 'homo' does not stand for human nature, but for the person sustaining human nature. This is also the case in regard to 'Deus' in the proposition "Deus genuit Deum": 'Deus' does not stand for the Deity itself, neither in forma absoluta, nor in habente ipsam, but stands rather for a divine suppositum or person. Furthermore, this is not due to any qualifying adjunct in the proposition "Deus genuit Deum" which restricts 'Deus' to stand for a person. 'Deus', as a concrete term, in a proposition where it stands for its significate, stands by that very fact for a divine person.

What explains this difference between Ockham, on the one hand, and Thomas and Henry, on the other? There are a number of issues involved. First, Ockham's theory of signification is different from that of Thomas and Henry. Thomas and Henry follow the traditional view flowing from Boethius's explanation of what Aristotle declares in Perihermenias, that "words are signs of passions in the soul." 25 Boethius, following Porphyry, states that: "[a]lthough verbal expressions signify things and concepts, principally they signify concepts and signify by a secondary signification the things which the intellect itself grasps by means of the concepts." 26 Aquinas, walking in Boethius's footsteps, explains:

'Passions in the soul' must be understood here as concepts in the intellect, and names, verbs, and speech, signify these conceptions of the intellect immediately according to the teaching of Aristotle. They cannot immediately signify things, as is clear from the mode of signifying, for the name 'man' signifies human nature in abstraction from singulars; hence it is impossible that it immediately signify a singular man. The Platonists for

24. William Ockham Scriptum in I Sententiarum 4.1, ed. Girard I. Etzkorn, Opera theologica 3 (St. Bonaventure: Franciscan Institute, 1977), pp. 3-17.

25. Aristotle On Interpretation $1(16 \mathrm{a} 3-4)$.

26. Boethius In librum De interpretatione, editio altera 1 "De signis" (PL 64:407C). 
this reason held that it signified the separated idea of man. But because in Aristotle's teaching man in the abstract does not really subsist, but is only in the mind, it was necessary for Aristotle to say that vocal sounds signify the conceptions of the intellect immediately and things by means of them. 27

Now Ockham's theory of signification is clearly different from the more traditional Boethian one. He writes,

Names of this type 'Man', 'animal', 'lion' and universally all first-intention names primarily and principally signify the things themselves outside the mind. The word 'man' primarily signifies all men and the word 'animal' primarily signifies all animals. And the same holds for other words of this type. ${ }^{28}$

Since all concrete first-intention words primarily and principally signify things outside the mind, and there are, for Ockham, no universal things, such words must primarily and principally signify not essences distinct in any way from the individuals, but the individuals themselves. In short, Ockham's theory of signification concerning concrete terms, namely that they primarily and principally signify things, is linked to his theory of universals. For him, there are no universal things, nor any universal natures in things that in some real way are distinct from individuals. When you couple his theory of signification with his theory of universals, the result is that, since a concrete term primarily and principally signifies a thing and the only things are individuals, then concrete terms must primarily and principally signify individuals.

If we swing back to the theological context of Sentences 1.4 , we can see Ockham's consistency. ${ }^{29}$ As 'man', 'animal', and 'lion' primarily and principally signify men, animals, and lions, that is individuals, so 'Deus' signifies primarily and principally the divine persons. And just as 'man' does not specify Socrates, Plato, or Cicero, so 'Deus' does not specify Father, Son, or Holy Spirit. Still, 'Deus' primarily and

27. Thomas Aquinas Super Perihermenias 2.5, in Aristotle: On Interpretation, trans. Jean Osterle (Milwaukee: Marquette Univ. Pr., 1962), p. 25.

28. William Ockham Expositio in librum Perihermenias 2.8.12, ed. Angelus Gambatese and Brown, Opera philosophica 2 (St. Bonaventure: Franciscan Institute, 1978), p. 502.

29. William Ockham Scriptum in I Sent. 4.1 (Etzkorn 12). 
principally signifies a person, not the divine essence, whether that essence be considered absolutely or as present in a supposit.

Although first-intention names primarily and principally signify individuals outside the mind and stand for or supposit for such individuals, they can in certain propositions have their supposition restricted by a qualifying adjunct. ${ }^{30}$ For instance, in the propositions "Man is a species" or "'Man' is a one-syllable word," the term 'man' is not used significatively or according to what it primarily and principally signifies. In brief, the primary form of supposition for Ockham is personal supposition, the type of supposition a term has in a proposition when it stands for its significate. In the case of concrete names, the principal and primary significate is the individual or supposit; it is for this supposit that a concrete term stands when it is a case of personal supposition. In this he differs from Thomas, Henry, and many others for whom simple supposition is primary. For them simple supposition takes place when a term in a proposition stands for its significate, by which they mean the essence-either taken absolutely or as present in an individual or supposit. Personal supposition is, for them, secondary: it takes place when a term stands for one of the inferiors contained under the essence or significate.

The primacy of personal supposition within Ockham's framework flows from his theory of signification and his theory of universals. Once you accept his position that concrete words signify things and join to it the thesis that the only things are individuals, Ockham's supposition theory, with the primacy of personal supposition, follows of necessity. It is from this viewpoint and from these assumptions that Ockham criticizes Thomas and Henry. Looking at Thomas's Summa 1.39.4, Ockham states: "In eadem quaestione non tantum realiter sed vocaliter idem condedit et negat." 31 Why?

Thomas said "ex modo significandi" 'Deus' can stand for a person, then later added that 'Deus' stands per se for the divine essence and per adiunctum for a person. In Ockham's eyes that is a contradiction. When a terms stands for something precisely by reason of an adjunct, then it does not supposit for it by reason of its modus significandi. For Ockham the concrete term has a way of signifying that points 
primarily to the supposit; it does not need an adjunct, therefore, to stand for the supposit. For Ockham, it needs an adjunct not to stand for the supposit.

From Ockham's viewpoint, Henry of Ghent's position is likewise faulty. A concrete term has to supposit for that in which its form is found: 'album' doesn't supposit for whiteness but for the subject in which whiteness is found. The abstract term 'albedo' signifies whiteness. The concrete term 'album' is more complex: it is not an absolute term, but a connotative one. 'Album' signifies one thing directly and another indirectly. Directly it signifies a subject; indirectly it signifies the whiteness present in the subject. The same holds for 'Deus'. It is a concrete term that directly signifies a supposit, indirectly the divine nature or essence that exists in the subject. Its primary significate, however, is the subject or supposit; only secondarily and indirectly does it signify the divine essence.

Henry's theory of signification and his theory of universals support the opposite position. The primary significate for him is the essence. He even refuses to speak of a secondary or indirect significate or consignificate. "Unde hoc nomen 'Deus' non significat nisi deitatem quam significat hoc nomen 'deitas', quemadmodum 'album' significat solam albedinem sicut et hoc nomen 'albedo', ita quod hoc nomen 'Deus', quantum est ex parte rei significatae, non significat aliud quam significetur hoc nomine 'deitas'."32

\section{WALTER CHATTON}

Walter Chatton and William of Ockham spent the early 1320s teaching together. ${ }^{33}$ Chatton knew Ockham's works well and criticized them frequently. Ockham's theory of supposition was no exception: Chatton criticized it in the fourth distinction of his Lectura in I Sententiarum, which we have edited below.

32. Henry of Ghent Summa $54.3\left(2: 81^{\mathrm{v}}-82^{\mathrm{r}}\right)$.

33. Compare Stephen F. Brown, "Walter Chatton's Lectura and William of Ockham's Quaestiones in libros Physicorum Aristotelis," in Essays Honoring Allan B. Wolter (St. Bonaventure: Franciscan Institute, 1986), pp. 81-115. 
The chief difficulty Chatton found with Ockham in this quaestio centers on the general theory of supposition held by the Venerable Inceptor. For Ockham, personal supposition, as we have seen, takes place when a term supposits for its significate, the individual it stands for. In the proposition "Homo currit," 'homo' signifies and stands for a real individual man. Since universals are, for Ockham, words or concepts, never things distinct in some real or formal manner from the individuals, simple supposition takes place when a term stands for a concept. The term 'man' in the statement "Man is a species" does not stand for a universal reality or a common nature in reality but for a universal or common concept. In brief, Ockham's account of supposition follows his theory of universals.

Chatton's theory of universals is different from Ockham's, and this is manifest in his definitions of the different types of supposition. Simple supposition, for Chatton, is manifold. Sometimes a term stands, as it does for Ockham, for a concept or a written or spoken word. At other times, however, we have cases of simple supposition where a term stands for a thing; here Chatton differs from Ockham. ${ }^{34}$

For Chatton, terms both in simple and in personal supposition can stand for things. Yet, he is careful not to make his distinction between simple and personal supposition follow a form of realism where he would claim that a term taken simply, or in simple supposition, stands for a universal thing, whereas a term taken personally, or in personal supposition, stands for a singular thing. He therefore frames his definitions in the following words:

Personal supposition takes place when a term so stands for a singular individual that the predicate of that proposition can be verified of a proper concept of that thing. ${ }^{35}$

The type of simple supposition that stands for a thing is that by which the subject of a proposition so stands for a thing that is really singular that the predicate of that proposition is not capable of being verified of a proper concept of that thing. ${ }^{36}$

34. See the edition below, nos. 8 and 6-6.1.

35. See no. 6 , below.

36. See no. 6 , below. 
Chatton takes great pains to explain the theory of universals which supports ${ }^{37}$ this theory of supposition, ${ }^{38}$ perhaps because it comes so close to the position of Henry of Harclay, which Ockham attacked in his Scriptum in I Sententiarum 2.7.39 Furthermore, Chatton seems aware that if for him a common term sometimes signifies a reality, and not just a common concept or a common spoken or written word, he might be vulnerable to Ockham's struggle against any claim that a thing can be the subject or predicate of a proposition. Chatton phrases Ockham's doubt in the following words:

I prove that the subject of this proposition "Man is a species" does not supposit for a thing outside the mind, since 'to be a species' is a second intention just as 'to be predicated of many' is a second intention, and a second intention does not belong to a thing that is signified. ${ }^{40}$

Chatton answers this objection by distinguishing between the admissible and inadmissible meanings that can be given to the phrase 'predicable of many'. If one intends to imply that some thing outside the mind really through its proper entity can be the predicate of a proposition, then certainly such an outside thing cannot be the predicate of a proposition. If, however, you mean by a thing being predicated that a thing outside the mind that is predicated of many is signified per se and primo by the predicate, then Chatton claims that this is admissible. For it is true, Chatton argues, that human nature, for instance, is signified per se and primo by the concept of man or by the definition 'rational animal', and that such a concept or definition can be predicated of many. 41

The traditional question of Sentences 1.4 "utrum Deus generet Deum?" allows Chatton to make these clarifications concerning his definitions of supposition and his theory of universals. On the traditional question, nonetheless, there is no serious objection to Ockham's own answer. Chatton's disagreements are minor; they seem strained.

37. See no. 6 , below.

38. See no. 6 , below.

39. William Ockham Scriptum in I Sententiarum 2.7, ed. Brown and Gedeon Gàl, Opera theologica 2 (St. Bonaventure: Franciscan Institute, 1970), pp. 227-248.

40. See no. 7.1, below.

41. See no. 8.2 , below. 
Both he and Ockham hold that 'Deus' and 'Deum' have personal supposition in the proposition "Deus generet Deum." Since there is no essential difference in the two men's views of personal supposition itself, there is no serious disagreement on the question inherited from Abelard. 42

Chatton's text that is edited below provides one example of the theological context within which he and other medieval thinkers developed their theories of supposition. Any careful reader of Ockham's Summa logicae would see how often this same example and many other theological examples served as major challenges to the logical theory of supposition. Logic rules and theory to a very great extent were developed to solve such theological challenges. Much broader studies of Chatton, of Ockham, and of most medieval thinkers would be well worth the effort.

Boston College

\section{APPENDIX}

[WALTER CHATTON/LECTURA IN I

SENT. 4.1.1-2]

generet ${ }^{1}$ Deum:

[1.0] Circa distinctionem quartam quaero utrum Deus

[1.1] Quod non, quia si sic, aut igitur haec esset vera per se aut per accidens. Non primum, quia sic omnis Deus generaret Deum. Non per accidens, quia tunc sibi non repugnaret non generare Deum, et per consequens sibi non repugnaret esse sine Filio Deo. ${ }^{2}$

[1.2] Secundo, quia omnis Deus est necesse esse. $\mathrm{Si}^{3}$ igitur Deus generaret Deum, tunc necesse esse generaret necesse esse. Quod falsum, quia tunc necesse esse ${ }^{4}$ necessario exigeret aliud a se ad hoc

42. See nos. 9.1-15.4, below.

1. generet/generat F (= Florence, Bibl. Naz. Cent. MS Conv. soppr C.5.357)

2. Deo/idem P ( = Paris, Bibl. Nat. MS lat. 15,886 )

3. Si/quia $F$

4. esse/est $P$ 
quod esset, et per consequens illo alio circumscripto ipsum non esset, igitur ipsum non est necesse esse.

[1.3] Contra: Pater generat Filium et uterque est Deus, igitur Deus generat Deum.

\section{[1.4] [DIVISIO QUAESTIONIS]}

In ista quaestione unum supponitur et aliud quaeritur. Supponitur enim quod in divinis una persona generet aliam personam. Et hoc supposito, quaeritur utrum ista propositio debeat concedi 'Deus generat Deum'. Admisso supposito tamquam certissimo ex fide, eo quod Filius a Patre solo est non factus nec creatus sed genitus, in ista tamen ${ }^{5}$ quaestione sunt duo facienda: primo enim aliqua sunt tangenda de suppositione per quae quaestio solvetur; secundo est per illa respondendum ad quaestionem.

\section{[2.0] [ARTICULUS PRIMUS] [OPINIO GUILLELMI DE OCKHAM]}

[2.1] Primus igitur articulus est tangere aliqua de suppositione per quae solvetur quaestio. Et hic est opinio Ockham in Primo, distinctionis 4 quaestione 1.6 Distinguit ${ }^{7}$ suppositiones in generali, dicens quod suppositio variatur dupliciter: quia aliquando variatur ex hoc quod supponit pro alio et alio et aliquando variatur ex hoc quod supponit aliter et aliter pro eodem.

[2.2] Suppositio isto secundo modo dividitur in suppositionem confusam tantum et in suppositionem confusam et distributivam; suppositio primo modo dividitur in ${ }^{8}$ suppositionem simplicem, materialem et personalem. Terminus enim in propositione vocali supponit simpliciter

5. tamen om. F

6. William Ockham Scriptum in librum primum Sententiarum 4.1, ed. Girard I. Etzkorn, Opera theologica 3 (St. Bonaventure: Franciscan Institute, 1977), pp. 7-13.

7. Distinguit/quae distinguit $F$

8. in suppositionem confusam et distributivam . . . in om.(hom.) $\mathrm{P}$ 
quando illa vox supponit pro conceptu. Licet enim vox non significet conceptum illum, tamen quia ista vox et iste conceptus sunt signa subordinata respectu eiusdem significati, ${ }^{9}$ ideo respectu praedicati quod convenit conceptui potest vox supponere pro conceptu, ut cum dicitur 'Homo est species'. Sed in propositione in mente terminus supponit simpliciter quando supponit pro se ipso et non pro re extra, ut patet de ista 'Homo est species'-ut patet distinctionis 2 quaestionibus 4 et 5 et alibi frequenter. ${ }^{10}$ Terminus ${ }^{11}$ autem supponit materialiter quando supponit pro ipsa voce, ut in ista 'Homo est nomen'. Sed terminus supponit personaliter quando supponit pro ipso individuo reali significato. 12

\section{[3.0] [CONTRA OPINIONEM GUILLELMI DE OCKHAM]}

Contra ista: primo, non videtur verum quod vox supponat pro conceptu quem non significat, quia supponere pro aliquo est stare loco sui sicut signum pro significato. ${ }^{13}$

[3.1] Item, si in ista propositione in voce 'Homo est species' subiectum supponat pro conceptu, igitur idem est dicere quod 'Iste conceptus est species'. Sed istae voces quas formavi cum dixi "Iste conceptus" vere significant illum conceptum.

[3.2] Item, sicut conceptus dicitur species seu illud quod est praedicabile de pluribus in propositione in conceptu, eadem ratione haec vox "homo" dicetur species seu $\mathrm{id}^{14}$ quod praedicatur de pluribus in propositione in voce. Qua ratione igitur in propositione in voce vox, si supponat simpliciter, supponit pro conceptu communi, eadem ratione in propositione in mente si conceptus supponat simpliciter supponit

\section{9. significati/signati $P$}

10. William Ockham Scriptum in librum primum Sententiarum 2.4-5, ed. Brown and Gedeon Gàl, Opera theologica 2 (St. Bonaventure: Franciscan Institute, 1970), pp. 135, 157. Compare Ockham Summa logicae 1.64, ed. Philotheus Boehner et al., Opera philosophica 1 (St. Bonaventure: Franciscan Institute, 1974), p. 195.

11. Terminus/Tres $P$

12. significato/signato $P$

13. significato/signato $P$

14. id/idem $P$ 
pro $^{15}$ voce communi vel alio signo corporali, [ut] cum intellectus format hanc ${ }^{16}$ propositionem 'Haec vox "homo" praedicatur de pluribus'. Et si ponas quod hoc non sit necesse, eadem ratione dicam quod ibi non sit necesse.

[3.3] Secundo, non apparet verum quod in propositione in mente quando conceptus supponit simpliciter supponit pro se ipso, quia tunc significaret ${ }^{17}$ se ipsum; sed significari ${ }^{18}$ per intentionem est intelligi; igitur iste conceptus est intentio sui ipsius, et per consequens omnis cognitio intellectiva esset cognitio sui ipsius, quod falsum est, sicut patet in prima quaestione Prologi, articulo primo ${ }^{19}$ - reducendo primum argumentum contra opinionem, et etiam de prima. ${ }^{20}$

[3.4] Item, eadem ratione in propositione in voce: si vox supponat simpliciter, supponit pro se ipsa.

[3.5] Item, in propositione in mente conceptus potest supponere materialiter ita bene sicut vox in propositione in voce; et hoc non possent ipsi salvare nisi ponendo quod tunc conceptus supponat pro se multo magis quam ${ }^{21}$ quando supponit simpliciter.

[3.6] Item, in ista propositione 'Homo est species' vel in ista 'Homo praedicatur de pluribus' "praedicari de pluribus" non convenit illi subiecto pro se sed pro re, nam cum "homo" praedicatur in istis 'Sortes est homo', 'Plato est homo', praedicatur de eis pro rebus extra secundum eos. 22 Igitur subiectum istius propositionis, si supponit pro conceptu, hoc erit in ordine ad rem significatam; igitur licet immediate supponat pro conceptu, tamen ${ }^{23}$ mediate supponit pro re significata per conceptum illum. Aut igitur pro re communi, et istam negant; ${ }^{24}$

15. conceptu [lin. 5] ... pro om.(hom.) P

16. hanc/habeat $P$

17. significaret/signaret $P$

18. significari/signari $P$

19. Maria Elena Reina, "La prima questione del prologo del 'Commento alle Sentenze' di Walter Catton," Rivista critica di storia della filosofia 25 (1970): 53.90_ 59.281; also Chatton, Reportatio et Lectura super Sententias: Collatio ad librum primum et prologus, ed. Joseph C. Wey (Toronto: PIMS, 1989) 24.213-27.279.

20. Namely of the first opinion reported and refuted there, that is, of the first opinion of William Ockham.

21. quam om. $\mathrm{P}$

22. Namely according to William Ockham, Summa logicae 1.64 (Boehner et al. $195)$.

23. tamen om. $\mathrm{P}$

24. William Ockham Summa logicae 1.64 (Boehner et al. 195). 
aut pro re singulari. Tunc mediate saltem supponit personaliter, quia secundum $\operatorname{eos}^{25}$ hoc est supponere personaliter: supponere pro supposito reali significato. ${ }^{26}$ Igitur si supponat mediate pro illo individo vel supposito, tunc supponit personaliter mediate.

[3.7] Confirmo, quia cum dicitur quod Sortes praedicatur de uno solo, quaero utrum subiectum supponat simpliciter vel materialiter vel personaliter. Non simpliciter, quia subiectum non est commune; nec materialiter, quia stat significative. Si personaliter, igitur cum suppositione personali stat quod immediate supponat pro conceptu et mediate pro re significata per illum.

\section{[4.0] [OPINIO REDUCENS OMNEM SUPPOSITIONEM AD SUPPOSITIONEM PERSONALEM]}

Quantum igitur ad istud diceret forte aliquis ${ }^{27}$ quod omnis suppositio est personalis, tam suppositio simplex quam materialis, quam etiam quaelibet alia, quia quilibet terminus supponens supponit pro aliquo singulari quod significatur ${ }^{28}$ per ipsum. Aut enim supponit pro re extra singulari quod significat; ${ }^{29}$ tunc habetur intentum. Aut significat ${ }^{30}$ conceptum aliquem et supponit pro illo: adhuc tunc supponit pro una singulari qualitate sive illa qualitas sit eadem cum ipsomet conceptu supponente sive non sit eadem sibi, ut verius credo. ${ }^{31}$

Aut significat ${ }^{32}$ vocem unam et supponit pro ea sive illa sit eadem cum subiecto supponente sive non, adhuc supponit pro quadam qualitate significata per ipsum. Et eodem modo de scripto arguendum est, et etiam de quocumque alio signo.

25. William Ockham Summa logicae 1.64 (Boehner et al. 195).

26. significato/signato $\mathrm{P}$

27. This opinion, here presented as possible, will later be held by Peter of Mantua. Compare Paul of Venice Logica magna: Tractatus de suppositionibus, ed. Alan R. Perreiah (St. Bonaventure: Franciscan Institute, 1971), pp. xi, 53-73.

28. significatur/signatur $\mathrm{P}$

29. significat/signat $P$

30. significat/signat $P$

31. See Gedeon Gàl, "Gualteri de Chatton et Guillelmi de Ockham controversia de natura conceptus universalis," Franciscan Studies 27 (1967): 191-212.

32. significat/signat $P$ 
[4.1] Diceretur igitur quod suppositio personalis sumitur dupliciter: uno modo large pro suppositione qua terminus supponit pro re singulari significata per illum terminum. Et isto modo suppositio personalis non dividitur contra suppositionem simplicem et materialem sed est communis eis, quia omnis suppositio materialis vel simplex est suppositio personalis isto modo et non e contra. Alio modo sumitur suppositio personalis stricte, eo modo scilicet quo condividitur contra suppositionem materialem et simplicem, et sic est suppositio qua terminus ${ }^{33}$ supponit pro singulari significato per ipsum non mediante suo signo sed immediate. Diceretur enim quod suppositio materialis est quando terminus supponit pro signo aliquo non in ordine ad suum significatum, sive in scripto, sive in propositione in voce, sive in mente, ut in istis 'Homo est vox', 'Conceptus est qualitas'. Suppositio simplex est qua terminus supponit pro signo in ordine ad suum significatum, sive in voce, sive in scripto sive in conceptu, ut in ista 'Homo praedicatur de pluribus'. Sed suppositio personalis isto modo est illa qua ${ }^{34}$ terminus supponit non pro signo rei sed pro re extra significata ${ }^{35}$ per ipsum, ut in ista 'Homo currit'.

\section{[5] [CONTRA ISTAM OPINIONEM]}

Iste modus dicendi, licet posset sustineri, habet tamen dubitationem: primo, quod non omnis suppositio sit suppositio personalis, sumendo ${ }^{36}$ eam generalissime, quia quando unus terminus supponit pro alio termino communi ista non est suppositio personalis, ut in ista 'Homo praedicatur de pluribus'. Licet enim subiectum supponat pro uno conceptu vel voce singulari in essendo, tamen supponit pro illo conceptu vel voce quatenus est communis in significando, et per consequens non est suppositio personalis.

[5.1 ] Secundo est dubium, quia sumendo ${ }^{37}$ suppositionem personalem stricte, isto ${ }^{38}$ modo, tunc non videtur divisio suppositionis

33. terminus/res $\mathrm{P}$

34. qua om. $\mathrm{P}$

35. significata/signata $P$

36. sumendo/sustinendo $F$

37. sumendo/sustinendo $F$

38. isto/eo $\mathrm{F}$ 
sufficiens in simplicem, materialem, et personalem, sicut patet de ista propositione 'Sortes praedicatur de uno solo'. Subiectum enim in ista non videtur supponere aliquo istorum modorum, ut supra dictum est. ${ }^{39}$ Item, tunc hic est suppositio simplex 'Homo est vox significativa'; et hic similiter 'Conceptus est qualitas cognitiva', quia subiectum supponit pro signo in ordine ad significatum.

[5.2] Tertio est dubium in isto modo dicendi, quia termini multi supponunt simpliciter et tamen supponunt pro re extra. Patet in exemplis:

[5.3] Primum exemplum est de subiecto istius propositionis 'Homo est substantia secunda', sicut habetur in Praedicamentis. ${ }^{40} \mathrm{Si}$ dicatur quod subiectum istius supponit pro conceptu quia sensus propositionis est quod de conceptu hominis sumpto significative praedicatur hoc praedicatum "substania secunda"; contra: 41 aeque dicam tibi quod in ista propositione 'Homo currit' subiectum supponit pro conceptu, quia denotatur quod de conceptu hominis sumpto significative praedicatur hoc praedicatum "currere."

[5.4] Item, tunc habetur propositum, quia si hoc praedicatum "secunda substantia" sit verificabile de conceptu hominis significative sumpto et non verificatur de conceptu hominis sumpto significative secundum suppositionem personalem, igitur secundum suppositionem simplicem.

[5.5] Item, subiectum huius propositionis 'Homo est secunda substantia' non minus supponit significative quam subiectum huius propositionis 'Homo non est in subiecto' iuxta dictum Aristotelis ibidem in Praedicamentis 42 ubi ponit proprietatem communem omni substantiae tam primae quam secundae: quod non sit in subiecto. Sed subiectum istius propositionis 'Homo non est in subiecto' stat significative pro re extra ita bene sicut subiectum in ista 'Sortes non est in subiecto', quia sicut dictum est 'non est in subiecto' est proprietas uniformiter conveniens substantiae primae et secundae, igitur etc.

39. See above no. 3.7

40. Aristotle Categories 5 (2a10-17). Compare William Ockham Expositio in librum Praedicamentorum Aristotelis 4, ed. Gedeon Gàl, Opera philosophica 2 (St. Bonaventure: Franciscan Institute, 1978), pp. 162-171.

41. contra/est add. $\mathrm{P}$

42. Aristotle Categories 5 (2a10-17). Compare William Ockham Expositio in librum Praedicamentorum Aristotelis 4 (Gàl 149-154). 
[5.6] Secundum exemplum est de subiecto istius propositionis 'Homo est magis substantia quam animal'. Dicit enim Aristoteles ibidem in Praedicamentis ${ }^{43}$ quod inter substantias secundas species est magis substantia quam genus. Si dicatur quod subiectum huius supponit pro conceptu quia sensus propositionis est quod ad quaestionem factam per quid de isto homine convenientius respondetur quod est homo quam quod est animal. Contra: per istam rationem dicetur quod animal rationale sit magis substantia quam homo, quia convenientius respondetur quod est animal rationale quam quod est homo.

[5.7] Item, per istam propositionem 'Homo est magis substantia quam animal' aut intelligitur quod haec sit magis vera 'Homo est substantia' quam haec 'Animal est substantia'; tunc habetur propositum, quia hic "homo" stat significative, igitur ibi. Aut intelligitur quod hoc totale praedicatum "esse magis substantia quam animal" verificetur de subiecto isto; adhuc tunc habetur propositum, quia non verificatur de isto subiecto pro quocumque signo rei, quia nullum signum est magis substantia quam animal, igitur verificatur de subiecto illo significative sumpto pro re extra. Unde breviter illa propositio est vera et non pro aliquo conceptu vel voce vel scripto; igitur pro re extra significata 44 per subiectum illud.

[5.8] Tertium exemplum est de subiecto istius propositionis 'Homo est substantia, quae dicitur de subiecto et non est in subiecto'. Ibidem enim in Praedicamentis ${ }^{45}$ habetur quod substantia secunda non sit in subiecto sed dicitur de subiecto. Si dicatur quod subiectum istius stat pro conceptu, quia sensus propositionis est quod de homine significative sumpto praedicatur hoc praedicatum "substantia," quae dicitur de subiecto et non est in subiecto;--isto modo respondet Ockham ad istud exemplum et ad praecedentia in prima parte Tractatus sui de logica, capp. 32 et 34.46 Contra: tunc habetur propositum quod haec propositio sit vera prout subiectum supponit significative pro re extra, quia non supponit personaliter, quia Aristoteles non consideraret

43. Aristotle Categories 5 (2b8-9). Compare William Ockham Expositio in librum Praedicamentorum Aristotelis 8, ed. Gedeon Gàl and Brown, Opera philosophica 2 (St. Bonaventure: Franciscan Institute, 1970), pp. 176-177.

44. significata/signata $P$

45. Aristotle Categories 2 (1a20-21). Compare William Ockham Expositio in librum Praedicamentorum Aristotelis 4 (Gàl 149-154).

46. Rather chapters 42-43 (Boehner 118-132). 
istam 'Sortes est substantia quae est dicibilis de subiecto et non est in subiecto' eo quod negat hoc a substantiis primis; igitur stat simpliciter. Si dicatur ${ }^{47}$ quod dici de subiecto est praedicari, sed praedicari non convenit rei extra; ad istud dicetur infra. 48

[5.9] Quartum exemplum est de subiecto istius propositionis 'Equinitas nec est de se una nec plures', et similiter de subiecto istius propositionis 'Humanitas non est de se Sortes nec Plato', et sic de singulis.

[5.10] Et similiter de subiecto huius propositionis 'Humanitas non requirit per se quod ipsa sit Sortes vel Plato', et sic de singulis.

[5.11] Ad primum istorum dicit Ockham, in Primo, distinctionis secundae quaestione quinta versus finem, ${ }^{49}$ quod per illam propositionem intelligitur quod nec unum nec plura cadit in definitione equinitatis. Contra: eadem ratione haec est vera 'Humanitas nec est de se una nec plures', et similiter ista propositio 'Animal rationale vel animalitas rationalitas nec est de se una nec plures', et tamen istam ultimam propositionem non contingit sic glossare, quia animalitas rationalitas non habet definitionem, quia sic definitionis esset definitio in infinitum.

[5.12] Ad secundum dicitur eadem quaestione: 50 cum dicitur quod 'Natura humana non est de se Sortes' aut sumitur ibi subiectum personaliter; sic est propositio vera pro Platone, et similiter sua subcontraria vera pro Sorte: 'Natura humana est de se Sortes'. Aut sumitur simpliciter pro $^{51}$ conceptu; sic vera est, quia universalis conceptus ille non est de se Sortes. Contra: licet haec propositio sit vera 'Natura humana non est de se Sortes' 52 prout subiectum supponit personaliter pro Platone, tamen ista propositio non est vera si subiectum supponat personaliter 'Natura humana nec est de se Sortes nec Plato nec Cicero', et sic de singulis. Haec enim est falsa 'Plato non est de se Sortes nec Plato', 53 et sic de singulis. Nec stat ibi subiectum pro conceptu, quia haec copulativa est vera Natura humana est de se

47. Compare William Ockham Summa logicae 1.32 (Boehner et al. 94-95).

48. See below, no. 8.2.

49. William Ockham Scriptum in I Sent. 2.6 (Brown \& Gàl 219).

50. William Ockham Scriptum in I Sent. 2.6 (Brown \& Gàl 198-200).

51. Sorte... pro om.(hom.) P

52. Contra... Sortes om.(hom.) $\mathrm{P}$

53. nec Cicero... Plato om. P 
realis humanitas extra et tamen natura humana nec est de se Sortes nec Plato' et sic de aliis. Et sicut subiectum primae partis istius copulativae supponit pro re extra, ita et subiectum secundae partis istius copulativae supponit pro re extra.

[5.13] Quintum exemplum est de subiecto istius propositionis 'Homo est primo animal rationale', 'Homo est primo risibilis', et sic de consimilibus. Hic dicit Ockham, in prima parte Tractatus de logica, cap. $65^{54}$ quod Philosophus intelligit quod "risibile" praedicatur convertibiliter de homine et "animal rationale" praedicatur convertibiliter de ista intentione "homo," et ad istum intellectum subiectum supponit pro ipsa intentione animae; et idem dicit in Primo, distinctionis secundae quaestione quarta. ${ }^{55}$ Contra: non sufficit quod praedicatum et subiectum convertantur ad hoc quod praedicatum primo praedicetur de subiecto, nam si nullum animal esset nisi homo, adhuc haec non esset vera 'Homo est primo compositus ex corpore et anima sensitiva'; sed haec esset vera 'Animal est primo compositum ex anima sensitiva et corpore', 56 et tamen "homo" et "compositum ex corpore et anima sensitiva" converterentur. Item, ad hoc quod haec sit vera "Homo est primo risibilis' non sufficit quod "homo" et "risibile" convertantur sed requiritur quod "risibile" conveniat rei significatae per subiectum in quantum est homo et quod non conveniat alicui nisi in quantum ipsum est homo, et per consequens ad hoc quod haec sit vera 'Homo est primo risibilis' requiritur quod iste terminus "homo" supponat pro re extra cui conveniat risibilitas ex hoc quod ista res est homo et non nisi quia ipsa est homo.

\section{[6.0] [OPINIO AUCTORIS]}

Quantum igitur ad istud videtur aliter dicendum quod suppositio personalis est ${ }^{57}$ quando terminus supponit sic pro individuo singulari quod de eius conceptu proprio natum est praedicatum illius propositionis verificari, ut cum dicitur quod 'Homo currit' hic

54. William Ockham Summa logicae 1.66 (Boehner et al. 202-203).

55. William Ockham Scriptum in I Sent. 2.4 (Brown \& Gàl 99-152).

56. sed... corpore om. P

57. suppositio... . est om. F 
subiectum supponit pro Sorte pro quo est haec vera 'Sortes currit'. Suppositio materialis est ista qua subiectum supponit pro signo rei extra, ut 'Homo est nomen', 'Conceptus est qualitas'. Sed suppositio simplex pro re extra est illa qua subiectum sic supponit pro re extra quod praedicatum non est natum verificari de proprio conceptu illius rei extra, sicut posita sunt exempla praecedentia, et multa alia possent poni. Potest enim dici uno modo sic: quod iste homo et est Sortes et est homo et est animal, et sic de aliis. Tunc cum dicitur quod humanitas nec est de se Sortes, nec de se Plato, et sic de aliis, sicut nec de se unum vel plura, dici potest quod subiectum istius propositionis supponit pro illa re in quantum est homo et sibi repugnat respectu illius praedicati supponere pro illa re in quantum est Sortes, ideo haec non est vera 'Sortes non est de se Sortes nec Plato', et sic de aliis, et eodem modo de ista propositione 'Animal est substantia secunda', et sic de consimilibus. Alio modo potest dici quod licet natura humana pro qua subiectum illius propositionis supponit sit realiter Sortes, quia tamen supponit pro ea tali suppositione cui non repugnat formaliter quod natura pro qua supponit esset communis, ideo illud praedicatum non est natum verificari de proprio conceptu Sortis. Assumptum patet, quia haec consequentia non est formalis 'Subiectum illius propositionis supponit pro natura humana, igitur supponit pro Sorte vel ${ }^{58}$ Platone et sic de aliis', et per consequens oppositum consequentis non repugnat formaliter antecedenti, scilicet quod subiectum illius propositionis supponeret pro natura humana, et tamen nec supponeret pro Sorte nec Platone, et sic de aliis. ${ }^{59}$ Vel tertio modo potest dici quod verum est dicere quod subiectum illius propositionis supponit per se pro natura humana et non ${ }^{60}$ est verum dicere quod supponit per se pro Sorte; immo magis esset verum dicere quod sibi repugnat supponere per se pro Sorte, ideo etc.

[6.1] Patet igitur quod suppositio simplex est illa pro re extra qua subiectum propositionis sic supponit pro re quae est realiter singularis quod praedicatum illius propositionis non est natum verificari proprio conceptu singularis propter causas dictas. Nec istud debet esse extraneum tenentibus oppositum, quia ipsimet, ut videtur, habent

58. vel/pro add. F

59. et. . . aliis om. F

60. non om. $\mathrm{F}$ 
hoc concedere sicut tactum est. Ipsi ${ }^{61}$ concedunt istam propositionem 'De conceptu communi substantiae sumpto significative praedicatur secunda substantia'. Quaero igitur utrum conceptus communis substantiae, quando sumitur significative, sumitur pro substantia reali communi extra animam, et hoc negant; aut sumitur significative pro re singulari, et tamen de eius conceptu proprio sumpto significative non praedicatur secunda substantia secundum eos; igitur habent concedere quod de conceptu communi rei singularis sumpto [significative] pro illo singulari praedicatur aliquod praedicatum, et tamen illud praedicatum non potest vere praedicari de conceptu proprio eiusdem singularis.

\section{[7.0] [INSTANTIAE GUILLELMI DE OCKHAM]}

Contra: 62 subiectum istius propositionis 'Conceptus hominis praedicatur de pluribus differentibus numero' non supponit personaliter nec materialiter, igitur simpliciter, et per consequens quando terminus supponit simpliciter tunc supponit pro conceptu et non pro re extra.

[7.1] Item, probo quod subiectum istius propositionis 'Homo est species' non supponat pro re extra, quia "esse speciem" est intentio secunda sicut "praedicari de pluribus," sed intentio secunda non convenit rei significatae. ${ }^{63}$

\section{[8.0] [RESPONSIONES AD INSTANTIAS]}

Ad primum istorum potest dici sicut solet dici a multis $^{64}$ quod duplex est suppositio simplex: una qua terminus supponit simpliciter pro re extra sicut in exemplis suprapositis, et alia qua

61. Namely William Ockham Summa logicae 1.72 (Boehner et al. 222).

62. William Ockham Summa logicae 1.65 (Boehner et al. 198).

63. non. . . significatae om. P

64. For example, Walter Burleigh, for whom see Brown, "Walter Burleigh's Treatise De suppositionibus and its Influence on William Ockham," Franciscan Studies 32 (1972): 35-36. 
terminus supponit pro voce communi vel conceptu vel scripto in ordine ad significatum suum respectu praedicati quod est intentio secunda. Secundum istud concederetur quod ibi supponat suppositione una simplici, tamen praeter illam est alia suppositio simplex pro re extra, ut dictum est.

[8.1] Aliter potest dici quod triplex est suppositio materialis: una qua subiectum propositionis supponit pro voce vel conceptu vel scripto non in ordine ad aliquod significatum, ut cum dicitur "Iste conceptus "homo" est qualitas', 'Haec vox "homo" est sonus'; alia qua subiectum propositionis supponit pro voce vel conceptu vel scripto, licet in ordine ad significatum, et isto modo potest dici in proposito quod est suppositio materialis. Nec istud videtur magnum inconveniens, nam respectu passionis grammaticalis subiectum supponit materialiter et tamen pro voce vel conceptu vel scripto in ordine ad significatum, ut cum dicimus quod "Homo" est nomen substantivum', "Homo" est nomen significativum'.65 Tales enim praedicationes verificantur pro signis in ordine ad significata sua et tamen ibi est suppositio simplex. Ita, ut videtur, potest dici in proposito de passionibus logicalibus, ut cum dicimus quod 'Conceptus hominis praedicatur de pluribus', quod hic subiectum supponit materialiter et tamen supponit pro uno signo, scilicet conceptu, aliquo modo 66 in ordine ad significatum suum. Tertio modo diceret qui vellet, ut tactum est supra, quod subiectum illius propositionis supponit personaliter, quia subiectum illius propositionis est actus reflexus et supponit significative pro actu recto qui est res extra ${ }^{67}$ singularis in essendo, licet sit communis in significando; et praedicatum illius propositionis est natum vere praedicari de proprio conceptu illius actus recti, igitur est aliquo modo suppositio personalis. Quiscumque istorum trium modorum ponendi detur non est magna cura quantum ad propositum, quia in proposito sufficit quod aliqua sit ponenda suppositio simplex respectu rei extra animam.

[8.2] Ad secundam obiectionem potest dici quod aliquid dicitur praedicabile de pluribus uno modo quia ipsum realiter per entitatem propriam natum est esse pars propositionis sequens copulam, et isto modo res extra non dicitur praedicari sicut nec subici; et sic

65. significativum/signatum $\mathrm{P}$

66. modo om. F

67. extra/vera $P$ 
sumitur "praedicari" in obiectione immediate praecedente cum dicitur quod 'Conceptus hominis praedicatur de pluribus'. Alio modo sumitur "praedicari" pro "significari 68 per se et primo per praedicatum quod praedicatur de pluribus." Et isto modo convenit rei extra, nam verum est dicere quod natura humana per se et primo significatur ${ }^{69}$ per conceptum hominis seu per istam definitionem "animal rationale," quae definitio nata est praedicari de pluribus. Unde sicut res extra dicitur cognoscibilis quia nata est significari per cognitionem, ita res extra dicitur praedicabilis quia per se et primo nata est significari ${ }^{70}$ per praedicatum.

[8.3] Consimiliter est dicendum de specie cum dicitur 'Homo est species'. Aut enim sumitur ibi "species" pro illo quod praedicatur de pluribus eo modo quo pars propositionis praedicatur, et tunc patet quod subiectum istius propositionis supponit pro voce vel conceptu vel scripto; aut prout est idem quod per se et primo significari per praedicatum quod est pars propositionis communis multis, et isto modo res extra est species sicut humanitas; aut propositio illa valet istam 'Homo est natura quaedam specifica' et sic adhuc convenit rei extra. Ex isto patet illud quod tactum est supra, primo exemplo, quod eadem res extra ex hoc quod est Sortes est substantia prima et ex hoc quod est homo est substantia secunda, et similiter ex hoc quod est animal, et sic de consimilibus. Et eodem modo de tertio exemplo: ex hoc quod est homo ${ }^{71}$ convenit sibi per se et primo quod sit dicibile de substantia prima ista et illa ad intellectum praedictum, sed ex hoc quod est Sortes non convenit sibi hoc.

[8.4] Aliter adhuc posset dici si homo vellet quod aliter distinguit suppositiones artifex realis et aliter artifex sermocinalis, nam artifex realis considerans de rebus extra intelligit per suppositionem simplicem illam qua terminus supponit pro re singulari extra, et tamen praedicatum illius propositionis non est natum verificari de proprio conceptu illius singularis; et intelligit per suppositionem personalem illam, scilicet, qua terminus supponit sic pro re extra singulari quod praedicatum est natum verificari de proprio conceptu illius singularis; et intelligit per suppositionem materialem illam qua terminus supponit pro signo rei extra sicut pro conceptu, voce vel scripto sive supponat

68. significari/signari $\mathrm{P}$

69. significatur/signatur $\mathrm{P}$

70. significari/signari $P$

71. est substantia [lin. 11] . . homo rep. $\mathrm{P}$ 
pro illo in ordine ad significatum sive non. Logicus autem qui est artifex sermocinalis intelligit per suppositionem personalem sicut prius, sed per suppositionem simplicem intelligit illam qua terminus supponit pro signo in ordine ad significatum et hoc respectu praedicati quod est passio logicalis, cuiusmodi est intentio secunda, sive illud signum pro quo subiectum supponit sit vox sive conceptus sive scriptum, ut 'Homo est ${ }^{72}$ species'. Per suppositionem materialem intelligit illam qua subiectum supponit pro signo rei tam respectu praedicati grammaticalis, ut 'Homo est nomen' quam etiam respectu praedicati quod non convenit sibi in ordine ad significatum, ${ }^{73}$ ut 'Homo est vox', ita quod artifex realis omnem suppositionem, vocet suppositionem ${ }^{74}$ materialem qua terminus supponit pro signo rei sive illud signum sit vox sive conceptus sive scriptus et hoc tam respectu praedicati logicalis quam respectu praedicati grammaticalis quam etiam repectu praedicati quod non ${ }^{75}$ convenit signo in ordine ad significatum, et ideo apud eum omnis suppositio simplex est pro re extra; non sic logicus, ut dictum est.

\section{[9.0] [ARTICULUS SECUNDUS]}

Secundus igitur articulus huius quaestionis est solvere quaestionem. ${ }^{76}$

\section{[9.1] [OPINIO GUILLELMI DE OCKHAM]}

Ad quam dicit Ockham, ubi prius, distinctionis quartae quaestione prima, ${ }^{77}$ quod iste terminus "Deus" ex modo suo significandi solum supponit pro supposito, tamen ratione praedicati adiuncti supponit pro natura ex usu loquentium introducto ad vitandum errores et ad exprimendum identitatem summam quae est ibi. Et ideo quando praedicatum solum convenit supposito tunc solum supponit

72. est om. $\mathrm{P}$

73. significatum/signatum $P$

74. vocet suppositionem om.(hom.) F

75. non om. $\mathrm{F}$

76. quaestionem om. $\mathrm{P}$

77. William Ockham Scriptum in I Sent. 4.1 (Brown \& Gàl 12-13). 
pro supposito, et quando convenit naturae, solum supponit pro natura. Tunc ad quaestionem: haec propositio est vera 'Deus generat Deum', quia praedicatum solum convenit supposito, ideo subiectum ibi solum supponit pro supposito.

\section{[9.2] [CONTRA OPINIONEM GUILLELMI DE OCKHAM]}

Contra: dubium est utrum respectu cuiuslibet praedicati convenientis naturae possit iste terminus 78 "Deus" supponere pro natura, quia dicimus quod natura Patris est communicata Filio a Patre et tamen isti non concederent istam 'Deus Patris est communicatus Filio a Patre'.

[9.3] Similiter, per Magistrum, distinctione 34, cap. "Hic considerandum"79 haec est vera 'Una est essentia trium personarum', non tamen ista 'Deus est trium personarum'.

[9.4] Secundo, aliud est diminute dictum: quod subiectum solum supponat pro supposito ${ }^{80}$ quando praedicatum solum convenit supposito, quia tunc ita esset propositio universalis vera sic dicendo 'Omnis Deus generat Deum' sicut haec indefinita, quia non declarant ${ }^{81}$ quare illud praedicatum arctet magis subiectum ad solum standum pro uno quam arctet signum universale ad solum distribuendum pro uno. Similiter, forte non concederent istam 'Deus non est trinus et unus', licet concederent praedicatum solum convenire supposito. Hoc forte non concederent ne daretur aliis occasio errandi.

\section{[10.0] [OPINIO AUCTORIS]}

Aliter igitur potest dici ad quaestionem dupliciter: uno modo per praedicta quod propositio est absolute vera, nam ubi

78. terminus/tres $\mathrm{P}$

79. Peter Lombard Sententiae 1.34.2, ed. Ignatius Brady (Grottaferrata: CSB, 1971), p. 251.

80. supposito/significato $\mathrm{F}$

81. declarant/declaratur $\mathrm{P}$ 
terminus supponit personaliter ibi propositio ${ }^{82}$ est vera si praedicatum natum est verificari de proprio conceptu illius pro quo subiectum supponit. Sed ita est hic, quia subiectum istius propositionis 'Deus generat Deum' supponit pro prima persona, de cuius proprio conceptu verificari potest hoc praedicatum "generans Deum" sic dicendo: 'Ista persona non producta generat Deum', igitur etc.

[10.1] Unde iuxta praedicta contingit de divinis triplicem suppositionem praedictam assignare, ut videtur. Aliquando enim terminus supponit simpliciter de divinis, ut cum dicitur 'Deus est tres personae et quaelibet earum'. Ideo in talibus paralogismis est fallacia $\mathrm{ex}^{83}$ varia suppositione: 'Deus est tres personae et quaelibet earum; Deus est Pater; igitur etc', quia in prima propositione subiectum supponit simpliciter et in secunda supponit personaliter pro Patre. Aliquando etiam supponit personaliter, ideo variatur suppositio in talibus paralogismis: 'Hic Deus est Pater; hic Deus est Filius; igitur Pater est Filius', quia subiectum primae propositionis supponit personaliter pro Patre et in secunda supponit personaliter pro Filio. Aliquando etiam supponit pro signo, ut cum dicimus quod 'Conceptus ${ }^{84}$ Dei est qualitas', et sic etiam fiunt paralogismi sic arguendo: 'Haec sapientia divina est per se primo modo dicendi per se sapientia; sed haec sapientia divina est haec iustitia divina; igitur haec sapientia divina est per se primo modo dicendi per se haec iustitia divina'. Subiectum enim minoris supponit pro re extra, quia denotatur quod sapientia divina et iustitia divina sint una res extra. Sed subiectum maioris supponit pro una propositione, quia iste est sensus: haec propositio 'Sapientia divina est sapientia' est praedicatio per se primo modo dicendi per se. Hic enim subicitur iste terminus 85 "haec propositio" et supponit pro hac propositione 'Sapientia divina est sapientia'. Et similiter, sic arguendo 'Deus est Pater ingenitus; Deus est terminus communis; igitur Pater ingenitus est terminus communis', subiectum primae propositionis supponit pro re extra, sed subiectum secundae propositionis supponit pro conceptu vel alio signo rei. Patet igitur quod ista propositio potest concedi 'Deus generat Deum', quia subiectum supponit personaliter pro re de cuius proprio conceptu verificatur "generans Deum." 86

82. propositio/propositione $\mathrm{P}$

83. ex om. $\mathrm{P}$

84. pro Filio [lin. 12] . . Conceptus om. P

85. terminus/tres $\mathrm{P}$

86. Patet [lin. 27] . . . Deum om. F 


\section{[11.0] [INSTANTIAE]}

Contra: primo, quod 87 conceptus Dei supponit ibi pro hoc Deo qui est simul tres personae, igitur propositio est falsa. Assumptum patet, quia conceptus Dei primo significat hunc Deum, sed primo supponit pro suo primo significato, igitur etc.

[11.1] Secundo, conceptus Dei non supponit pro Patre nisi quia Pater est ipsa deitas, et per consequens deitas est primum significatum illius conceptus. Aut igitur supponit ibi pro deitate, igitur deitas generat Deum; aut non; tunc non supponit pro Patre, quia si non supponit pro suo primo significato non supponit pro secundario significato.

[11.2] Tertio, quia idem significant 'Deus generat Deum' et 'Deitas generat deitatem', quia concretum et abstractum idem significant; sed una istarum est falsa, igitur alia.

[11.3] Quarto, indefinita est vera pro aliquo individuo. Si igitur haec sit vera 'Deus generat Deum' non sufficit dicere quod sit vera pro persona sed requiritur quod sit vera pro aliquo individuo. Sed hic non potest dare individuum nisi "hic Deus" qui est trinitas et pro illo non est propositio vera, igitur etc.

[11.4] Quinto, melius salvantur veritates theologicae et melius vitantur difficultates in oppositum exponendo propositiones in quibus praedicantur notionalia de essentialibus per propositiones alias in quibus praedicantur essentialia de notionalibus, ut in proposito dicendo quod haec praedicatio 'Deus generat Deum' valeat istam 'Generans est Deus' et 'Genitum est Deus' ${ }^{88}$

\section{[12.0] [RESPONSIO AD INSTANTIAS]}

Dicendum quod istae obiectiones licet valeant contra illos qui ponunt quod propositio ista est primo vera pro hoc Deo, non tamen valent contra me.

[12.1] Dixerunt enim aliqui89 non solum quod "deitas" aliquo modo in re distingueretur a qualibet personarum sed etiam quod iste

87. quod/quia $P$

88. et... Deus om. $\mathrm{P}$

89. John Duns Scotus Ordinatio 1.4.2.1.11-13, ed. Commissio Scotistica, Opera Omnia 4 (Vatican City: Typis Polyglottis, 1966), pp. 5-7; Lectura in I Sent. 4.1.4-7, 
terminus "hic Deus" primo significat illam rem ut sic distinctam a personis et quod pro hoc Deo sic sumpto est haec primo vera 'Deus generat Deum'. Contra istam opinionem valent illae obiectiones, quia tunc ista propositio esset falsa 'Deus generat Deum' eo quod haec est falsa 'Deitas generat deitatem'; et similiter haec est vera 'Primo generans distinguitur a primo genito', quia nihil primo generat se. $\mathrm{Si}$ igitur "hic Deus" esset primo generans tunc "hic Deus" distingueretur a se.

[12.2] Obiectiones autem illae non sunt contra me. Ad primam illarum dicendum quod subiectum istius propositionis 'Deus generat Deum' supponit pro prima persona. Et ad probationem dicendum quod Pater est primum significatum illius subiecti pro quo scilicet illa propositio est vera, et hoc sufficit ad propositum. Sicut enim est verum dicere quod conceptus specificus hominis primo significat hominem et non significat ${ }^{90}$ per se et primo Sortem, et tamen significatum illius conceptus pro quo ista propositio est vera 'Homo currit' est Sortes, ita licet sit verum dicere quod conceptus specificus Dei per se et primo significet Deum et quod non significat ${ }^{91}$ per se et primo Patrem, tamen Pater est primum significatum pro quo ista propositio est vera 'Deus generat Deum'.

[12.3] Ad secundum dicendum quod Patri convenit ex hoc quod est Deus quod ille conceptus potest pro eo supponere, et concedo quod non est verum dicere quod ${ }^{92}$ supponat hic pro divinitate. Sed ex hoc non sequitur quod non supponit pro Patre. Et cum dicitur de primo significato, ${ }^{93}$ dicendum quod Pater est primum significatum pro quo ista propositio est vera, et hoc sufficit. Unde respectu huius praedicati non habet aliud significatum ${ }^{94}$ cui vere conveniat.

[12.4] Ad tertium patebit distinctione quinta.

[12.5] Ad quartum: ubi idem individuum est plures personae distinctae ad veritatem propositionis indefinitae sufficit quod verificetur pro una illarum personarum seu pro individuo illo in quantum est

ed. Commissio Scotistica, Opera Omnia 16 (Vatican City: Typis Polyglottis, 1960), pp. $408-409$.

90. significat/signat $\mathrm{P}$

91. significat/signat $\mathrm{P}$

92. non . . . quod om. P

93. significato/signato $\mathrm{P}$

94. significatum/signatum $P$ 
una illarum personarum, licet non verificetur pro illo individuo in quantum est omnes simul; ita est in proposito.

[12.6] Ad quintum: illa opinio reprobatur a Magistro Sententiarum, distinctione ista, de qua etiam dicetur quaestione proxima.

\section{[13.0] [ALIA RESPONSIO AUCTORIS]}

Alio modo potest responderi ad quaestionem distinguendo: cum quaeritur utrum haec sit concedenda 'Deus generat Deum', quaero: quid vis significare? Aut enim intendis quaerere utrum persona quae est Deus generet personam quae est Deus alia deitate; sic falsum est. Aut intendis quaerere utrum persona quae est Deus generet aliam personam quae est Deus eadem deitate; sic est verum.

\section{[14.0] [INSTANTIAE]}

Ut tamen istud magis appareat obicio in oppositum primo, quia eadem ratione diceretur quod Deus distingueretur a Deo.

[14.1] Secundo, quia tunc Deus generat alium habentem deitatem, igitur generat alium ab habente deitatem, et per consequens generat alium ab omni habente deitatem, quia negatio importata per ly alium negat illud quod sequitur confuse et distributive.

[14.2] Tertio, quia aut generat Deum qui est Pater aut Deum qui non est Pater. Si Deus generat Deum qui est Pater, igitur per conversionem Deus qui est Pater est genitus. Si genuit Deum qui non est Pater, igitur est aliquis Deus qui ${ }^{95}$ non est Pater et sic plures dii.

[14.3] Quarto, quia si sic: aut generat se Deum aut alium Deum eo quod generat eundem Deum vel diversum; non se Deum, quia nihil generat se, igitur alium Deum et sic plures dii. ${ }^{96}$

[14.4] Quinto, Deus genuit alium: aut igitur alium Deum, tunc sunt plures dii; aut alium non Deum, igitur genitus est non-Deus.

[14.5] Sexto, eadem ratione haec esset vera pro Filio: 'Deus non generat Deum'.

95. est Pater est [lin. 3] . . qui om.(hom.) P

96. Quarto [lin. 1] ...dii om.(hom.) P 


\section{[15.0] [RESPONSIONES AD INSTANTIAS]}

Ad primum istorum: non est simile, quia haec est absolute falsa 'Deus distinguitur a Deo', quia negatio importata in vocabulo distinctionis negat terminum sequentem distributive et universaliter, et ideo valet istam quae est simplicter falsa 'Deus non est idem alicui Deo'.

[15.1] Ad secundum: quid intelligis? Aut quod Deus generet alium in persona qui ${ }^{97}$ tamen habet eandem deitatem; sic potest concedi. Et similiter quod generet aliam personam habentem deitatem. Sed ex isto non sequitur quod genuit alium ab habente deitatem, quia sensus est quod genuit alium a quolibet habente deitatem; sicut nec sequitur 'Deus genuit non eundem habentem deitatem, igitur genuit non eundem alicui habenti deitatem'; patet quod non sequitur.

[15.2] Ad tertium quaeri potest: quid intelligitur? Aut sic: utrum Deus generet Deum qui est idem Deus cum Patre; sic concederetur, ex quo solum sequitur quod Deus genitus est idem Deus cum Patre. Aut intelligitur utrum Deus generet Deum qui est eadem persona cum Patre; sic est falsum, ex quo solum sequitur quod est aliquis Deus qui non est eadem persona cum Patre, et ex hoc non sequitur quod sint plures dii.

[15.3] Ad quartum potest similiter quaeri: quid intelligitur? Aut enim intendunt quaerere utrum genuerit se Deum ad istum intellectum, utrum scilicet genuit personam quae est idem Deus cum se ipso; et sic concederetur, nec ex hoc sequitur quod genuit se, quia sunt personae distinctae licet sint idem Deus. Aut quaeritur utrum genuit personam quae est idem personaliter secum; sic falsum est. Cum etiam quaeritur utrum genuit alium Deum: aut quaeritur utrum genuit alium qui est Deus; ${ }^{98}$ et patet quod sic. Aut quaeritur utrum genuit alium alietate deitatis; dicendum quod non.

[15.4] Ad quintum: aut quaeritur utrum genuit alium qui est Deus; potest dici quod sic, quia aliam personam quae est Deus. Aut quaeritur utrum genuit alium alietate deitatis; sic falsum est. Cum etiam quaeritur utrum genuit alium Deum: aut quaeritur utrum genuit alium

97. qui/quae $F$

98. Deus/Pater P 
qui non est Deus; sic falsum est. Aut quaeritur utrum genuit alium qui tamen non est alius alietate deitatis; sic est verum. ${ }^{99}$

\section{[16.0] [RESPONSIONES AD ARGUMENTA PRINCIPALIA]}

Ad primum principale: dicendum quod haec praedicatio non est per se primo modo dicendi per se, ut alias 100 dictum est. $\mathrm{Nec}$ est praedicatio per se secundo modo dicendi per se ad illum intellectum quo passio praedicatur de primo subiecto cum quo primo convertitur. Licet enim iste conceptus "generare Deum" sit conceptus primo convertibilis cum propria descriptione quidditativa absoluta primae personae, et ideo de illa praedicetur per se secundo modo dicendi per se secundum opinionem illam quae tacta est in tertia quaestione Prologi, articulo primo, in propositione ${ }^{101}$ tamen non est conceptus convertibilis cum conceptu isto communi omnibus personis cum dicitur "Deus," quia sic omnis qui est Deus generaret. Sed habet se ad illum sicut passio convertibilis cum conceptu inferiore se habet ad conceptum quidditativum superiorem, ut patet de ista propositione 'Animal est risibile' vel de ista 'homo generavit Platonem.' Genuisse enim Platonem est passio convertibilis cum proprio conceptu Sortis et praedicatur particulariter de conceptu communi hominis; ita in proposito secundum opinionem praedictam. Et cum arguitur quod tunc est per accidens: si intelligatur quod praedicatum conveniat subiecto per aliquod accidens seu etiam per aliquam rem distinctam in re a deitate, sic est falsum; nec consequentia valet. Si autem intelligatur sic quod "generare Deum" non convenit sibi in quantum est deitas sed magis per rationem extraneam, scilicet in quantum est talis persona, iste intellectus concederetur secundum opinionem illam, et ideo illi rei in quantum est deitas non repugnaret non generare Deum, sicut patet de Filio et Spiritu Sancto. Aliunde tamen

99. No reply to the sixth argument is found in the manuscripts.

100. Walter Chatton Lectura in I Sent. prol. 3.1, in Commento alle Sentenze, Prologo-question terza, ed. L. Cova (Rome, 1973), lin. 745-748; Wey 168.695-697.

101. Walter Chatton Lectura in I Sent. prol. 3.1 (Cova 751-767; Wey 169.700716). 
repugnat, scilicet in quantum est talis persona, ideo non potest esse sine Filio Deo.

[16.0] Ad aliud principale: conceditur quod necesse esse generat necesse esse ad illum intellectum quo conceditur quod Deus generat Deum. Et cum arguitur quod tunc necesse esse exigeret aliud a se: aut intelligitur quod necesse esse ${ }^{102}$ per unam necessiatem essendi exigeret necesse esse per aliam necessitatem essendi; sic falsum est, quia sicut sit una deitas ita sit una necessitas essendi. ${ }^{103}$ Aut intelligitur quod unum suppositum quod est necesse esse exigit aliud suppositum quod est necesse esse per eandem necessitatem essendi. Iste sensus, si poneretur, ${ }^{104}$ esset concedendus. Et cum dicitur quod tunc alio circumscripto ipsum non esset ${ }^{105}$ aut intelligitur quod, alio alietate necessitatis essendi circumscripto, ipsum non esset; sic falsum est, et non valet consequentia. Aut intelligitur ${ }^{106}$ quod alio alietate personali circumscripto, quod tamen est necesse esse per eandem necessitatem essendi, tunc ipsum non esset; sic est verum, quia illo circimscripto circumscriberetur propria necessitas essendi et propria deitas, igitur ipsummet circumscriberetur, et ex hoc non sequitur quin ipsum sit necesse esse sicut non sequitur ipsum non esset circumscripta propria necessitate essendi, igitur non est necesse esse modo de facto. Aliter posset responderi distinguendo de necesse esse formaliter vel privative, sed transeo.

102. esse/est $P$

103. sic falsum [lin. 5] . . . essendi om.(hom.) $\mathrm{P}$

104. poneretur/proponeretur $F$

105. concedendus [lin. 9] . . esset om.(hom.) P

106. intelligitur om. P. I want to thank Joseph C. Wey, C.S.B., for correcting this edition. 